\title{
The infancy Gospel of Thomas: Allegory or myth - Gnostic or Ebionite? ${ }^{1}$
}

A G van Aarde

(University of Pretoria)

\section{ABSTRACT}

The infancy Gospel of Thomas: Allegory or myth - Gnostic or Ebionite?

The aim of this article is to show that scholars assess the Infancy Gospel of Thomas disparagingly as "illogical", "un-Christian" and "banal". A more positive judgment is that it is either "Gnostic" or "purified of Gnosticism", or merely one of many ancient tales in the form of a historical allegory about Jesus as a child. The article argues that the author of the Greek version of the Infancy Gospel of Thomas in Codex Sinaiticus (Gr 453) describes the miracles of Jesus in a positive and negative light as if he were an adult. This phenomenon should be understood against the background that this second-century gospel is presented not so much in the genre of a Gnostic redeemer myth, but rather as a god-child myth that has neither an Orthodox nor a Gnostic orientation. Its context is rather early Ebionite Christianity.

This study is dedicated to all my students from 1980 to 2005 for loyalty over a period of twenty-five years at the University of Pretoria.

\section{INTRODUCTION}

This article is an attempt to understand why scholars assess the Infancy Gospel of Thomas (=IGT) disparagingly as "illogical" (Hervieux 1960:106), "un-Christian" (Elliott 1993:68) and "banal" (Schneider 1995). A more positive judgment is that it is either "Gnostic" (Lapham 2003:130) or, "purified of Gnosticism" (Klauck [2002] 2003:77), merely one of many ancient tales about the history of Jesus as a child (Hock 1995:96). The least likely possibility is Hans-Josef Klauck's (2003:77) view that it is an Orthodox version of

1 Paper read in partial fulfilment of the requirements for the Colloquium Doctum (D. Litt. Greek), Department of Ancient Languages, Faculty of Humanities, University of Pretoria, on 19 July 2005. 
a text with a Gnostic orientation ${ }^{2}$. The most positive assessment is found in the 2001 Toronto dissertation by Tony Chartrand-Burke. She views it as a "historical allegory".

In my doctoral thesis (Van Aarde 2005), I argued that the author of the Greek version of the IGT in Codex Sinaiticus (Gr 453) describes the miracles of Jesus in a positive and a negative light as if he were an adult and that this phenomenon should be understood in the light that the $I G T$ is presented not so much in the genre of a Gnostic redeemer myth, but rather as a god-child myth. I think that one of my most important contributions to the research on the $I G T$ is the argument that this second-century document has neither an Orthodox nor a Gnostic orientation, but that its context is rather the Ebionite early Christianity.

\section{HISTORY OF THE TEXT}

In a certain sense, the research for my thesis started 27 years ago, when as a young lecturer in the then Department of Greek I taught apocryphal gospels and used the Gospel of Peter and the Infancy Gospel of Thomas as sample studies. This year, 2005, I have been a lecturer in a permanent capacity for 25 years, and I am grateful to be able to put my research on this ancient and provocative text on paper

2 The critical remarks by church fathers such as Irenaeus and Epiphanius show clearly that the IGT was not regarded as part of early "Orthodox" Christianity. Moreover, the reference by Irenaeus (in his Adv Haer 1.20.1) is not to the most authentic manuscript (Codex Sinaiticus [Gr 4537), but to an extended manuscript that does contain "Gnostic" elements (namely the Codex Atheniensis [ $\mathrm{Gr} 355]$ ). There is no evidence that early readers were upset at the tales in the IGT. John Chrysostom (circa 386-398 CE) of Antioch (in his Homilae in Joannem 17) and Epiphanius of Salamis (376 CE) (in his Panarion 51.20.2-3) commented negatively on the tales, apparently not because their purport was offensive, but because they disputed John's claim $(\mathrm{Jn} 4: 46,54)$ that Jesus performed no miracles before his first sign in Cana. In the fourth century, within the context of early "Orthodox" Christianity, it was ideologically important that there should be harmonisation with the acknowledged gospels in accordance with the criterion of the regula fidei. That Jesus was responsible for "punitive miracles" created no ideological problems in terms of the expectations of ancient societies. Of all the earliest commentators on the $I G T$, only one in a sixth/seventh-century list of apocryphal books - inserted into the De receptione haereticorum by Timothy of Constantinople (see Patrologica Graeca [edited by J -P Migne] 86.22C) - refers to the IGT as "docetic" and "adoptionist", which conflicts with early "Orthodox" Christianity. 
at last. I would like to dedicate this study to all my students who showed such understanding and gave me such support on this academic journey.

The first publication of the $I G T$ in Greek was that of $\mathrm{J}$ Fabricius (1703:159-167) in the eighteenth century, which was followed by the publication of three manuscripts in the nineteenth century by Constantin von Tischendorf ([1874] 1876). On the basis of manuscripts available to him, he published two Greek texts (a longer one based on two manuscripts [Evangelium Thomae Graece $A$ ] and a shorter one based on one manuscript [Evangelium Thomae Graece B]) and a third in Latin (Vat lat 4578) (Hock 1995:99).

Initially, my attention was focused on a Greek manuscript that was available on microfiche in the library of the University of Pretoria. The only printed published text I could lay my hands on was that of A De Santos Otero (1967). I subsequently discovered that this Spaniard had used a publication of a fifteenth-century manuscript by A Delatte (1927), known as the Codex Atheniensis, to translate it into Slavic. It was this Codex Atheniensis that was available on microfiche in the university's Merensky library. I translated and grammatically explained all of these nineteen chapters of the manuscript word for word - a process that demanded considerable energy and perseverance, bearing in mind the laboriousness of working with a microfiche in the Africana section of the library in the "happy old university days" before the electronic era. After this, I began to attend to the other available manuscripts and early translations (for example those in Syrian, Arabic, Ethiopian, Latin, Georgian and Slavic). The two other Greek manuscripts, which are known as the Von Tischendorf texts, form part of the Codex Sinaiticus. These were then kept in the Saint Catherine monastery at the foot of Mount Sinai, but are now in London. The "shorter redaction" is known as Codex Sinaiticus (Gr 453) and the "longer redaction" as the Codex Sinaiticus (Gr 532). Then there is also another Greek manuscript, the Codex Bologna (Univ 2702).

3 See respectively Tischendorf ([1874] 1876:140-157 [Evangelium Thomae Graece A], 158-163 [Evangelium Thomae Graece B], 164-180) and discussion of the Greek of Evangelium Thomae Graece $A$ by Weissengruber (1978:225-226). 
My controversial involvement during the past years with the Westar Institute's Jesus Seminar drew my attention to the work of a fellow-seminarist, Ronald Hock, on other infancy gospels. But I soon found that Hock's (1995) Greek edition, translation and comments had not taken the available text-critical research on the $I G T$ into consideration either, especially that of Sever Voicu (1991, 1997) and Jacques Noret (1972). In his reproduction of a reliable Greek text, Hock selects now from one and then from the other of the two Greek Von Tischendorf texts and also often makes use of A Delatte's (1927) publication of the fifteenth-century Codex Atheniensis. In some places, he is also decisively guided by A De Santos Otero's (1967) Greek reconstruction based on his Slavic translation.

\section{ENCYCLOPAEDIC ECHOES}

My research travels took me from Israel (Tantur Institute for Theological Studies) to the Catholic University of Leuven in Belgium, to the USA (Westar Institute in Santa Rosa, California and the McCormick Theological Seminary in Chicago, Illinois) and finally to Egypt (Evangelical Theological Seminary in Cairo, Sint Catherine in Sinai and Nag Hammadi in Upper Egypt). I would therefore like to use this opportunity to express my indebtedness to all these institutions which put their facilities and libraries at my disposal. This research soon made me realise that the Codex Atheniensis (Cod Ath Gr 355) is the longest and evidently the least authentic manuscript ${ }^{4}$.

4 The final extension of the Greek version of the IGT in Codex Sinaiticus ( $G r$ 532) must have taken place at some stage before Tischendorf's $12^{\text {th }}$ century Latin manuscript (Vat lat 4578). In a parallel development during the composition of the Gospel of Pseudo-Matthew, the IGT became combined with the Infancy Gospel of James and several other tales about Jesus' stay in Egypt. In this process, the $I G T$ was extensively rewritten. However, this did not cause important parts of these separate tales to become lost. The name of the author was changed to James, probably to effect a smooth transition between the texts. The Latin texts, however, retained the name "Thomas". The vocabulary and syntax of the new text deviate so far from the Greek manuscript of the IGT in Codex Sinaiticus (Gr 453) and from the Greek version in Codex Atheniensis (Cod Ath Gr 355), however, that it must be regarded as an autonomous redaction product. Among the new tales there is at least one, namely "Jesus Revives a Salted Fish", in which mention is made of Peter as it is reported in the Acts of Peter, chapter 13. This element indicates how this new extended 
My understanding of the concept of "authenticity" is influenced philosophically, more specifically by Martin Heidegger's interpretation of the German word "eigentlich". In the introduction to his commentary on Heidegger, Michael Inwood (2000:26) puts it as follows: "To be authentic is to be true to one's own self, to be one's own person, to do one's own thing". To me, the hermeneutic question with regard to the manuscript and translation history of the $I G T$ was which version was the most faithful in terms of this document's "identity", based on a reconstructed context, that is to say in terms of the time and purpose of its writing. In Heidegger's ([1927] 1962:129) terms: Authenticity is eigentlichkeit and eigentlichkeit is faithfulness to the self in context.

I think that one of my most important contributions to the research on the $I G T$ is the argument that this second-century document has neither an Orthodox nor a Gnostic orientation, but that its context is rather the early Ebionite Christianity - even if Chartrand-Burke (2001) holds that the Ebionites "seem an ill fit".

text originated in the context of the broader corpus of early Christian literature. A second tale, the "Tale of the Teacher" in the prologue to the Greek version of the IGT in Codex Sinaiticus ( $G r$ 532]), chapters 5-6, seems to be a combination of chapters 2 and 6 of the Greek manuscript in Codex Sinaiticus (Gr 453). At some point in time before the fifteenth century, an editor of the Greek version of the IGT in Codex Bologna (Univ 2702) created an abbreviated text of only twelve chapters (eleven, in Tischendorf's numbering) (see Noret 1972; Voicu 1991, 1997; Chartrand-Burke 2001). This transmission of the introductory chapter and of the episode in the Greek manuscript in Codex Sinaiticus [ $\mathrm{Gr}$ 532], "Jesus Heals a Young Man" - the latter appearing after the episode "Jesus Resurrects the Boy Zeno" in the Greek version of the IGT in Codex Atheniensis (Cod Ath Gr 355) - is an indication that the new text is indeed an abbreviated form of the version with nineteen chapters in the collection. Both manuscripts were found in the Saint Catherine monastery at Mount Sinai. However, it is not clear whether a monastery scribe was responsible for this redaction.

5 According to Chartrand-Burke (2001), neither a Palestinian nor specifically a "Jewish-Christian" origin is needed to explain the $I G T$ 's connection with traditions in "formative Judaism". To explain the "Jewishness" of the $I G T$ is an environment in which the author probably came into contact with the post-70 CE Israelite tales, in which the portrayal of Jesus as an illtempered Palestinian holy man would give the least offence. Chartrand-Burke is of the opinion that if the IGT is in fact "Judeo-Christian", it can more likely be connected with the group that was responsible for the Gospel of the 
Following the view of Umberto Eco (1984) of "intertextuality", I see such a context as the "encyclopaedic echoes" that provide a reader with information on the culture, history and society that is "engraved" in the text.

As regards the Ebionites, the origin of the name is not quite clear (see Jones 1990:287-288). Tertullian and Hippolytus thought that a person called Ebion was the "founder" of a "Christian" faction that acquired the name "Ebionites". However, Irenaeus' and Origen's derivation of the name "Ebionites" from "the poor" seems more likely. The apostle Paul's reference to the "poor" Judeans in Galatians 2:10 and Romans 15:26 could have led to the earliest group of "Christians" in Jerusalem (see Van Aarde 2004:711-738) after the destruction of Jerusalem by the Romans in $70 \mathrm{CE}$ being called "Ebionites" in certain regions. Similarities between Ebionite thinking and Pseudo-Clement suggest that this group was active in the territory east of the Jordan. The Jerusalem group appears to have left Jerusalem already before $70 \mathrm{CE}$, but maintained close ties with Jerusalem and the family of Jesus. James, the brother of Jesus, actually was the leader of the Jerusalem group (cf Acts 15:13-21; Gal 2:19). The Hebrew word for "poor" is ebjōn ( $A$ low) (see Koehler \& Baumgartner 1994-2000). According to Irenaeus (see Jones 1990:287), the "Ebionites" (like the leaders of the first group of "Christians" in Jerusalem - cf Gl 2:1-14) were opposed to Paul because, of among other things, his critical perspective on the soteriological function of the law. On the other hand, the "Ebionites" held the Gospel of Matthew in high regard because Matthew emphasised the soteriological value of the law (see inter alia $\mathrm{Mt}$ 5:17-20). Furthermore, Jerusalem and the central position the Temple in Jerusalem fulfilled in Israelite society were important to the "Ebionites". The Israelite way of life was also fully upheld. The main characteristic of this group of early "Christians" was the particularly high value - with soteriological implications - they attached to the Jesus' ties with his biological relatives and with Israel as extended family. It is therefore understandable that variations exist in the early Christian literature about the attitude of the

Hebrews. This document refers to Jesus' pre-existence and contains a postresurrection appearance to James, to whom Jesus refers as "my brother". 
"Ebionites" towards the virginal conception of Jesus ${ }^{6}$. However, it was especially the aspect of adherence to the law and the relation with "Israel in the flesh" that distinguished them from groups with a "Gnostic" orientation.

\section{THE THOMAS TRADITION}

It is the obviousness of the name "Thomas" in the $I G T$, but also the clear allusion to the IGT in the Acts of Thomas 79, that prompt the question whether the $I G T$ might not be part of the Thomas tradition and therefore have a "Gnostic" orientation. The IGT was therefore compared with the main document in the Thomas tradition, namely the Gospel of Thomas (NHC II, 2) (see Evans, Webb \& Wiebe 1993:88-144).

The frequently quoted parallels include the GospThom 4 ("the man advanced in years will not hesitate to ask a small child of seven days about the place of life") with IGT, Codex Sinaiticus (Gr 453) 7:3 ("Friends, I ponder my shame, because I am an old man and have been conquered by a little child") ${ }^{7}$; GospThom 9 (the parable of the sower) with IGT, Codex Sinaiticus (Gr 453) 11 ("When Joseph back then sowed seed, the child Jesus also sowed one measure of wheat. And his father harvested 100 large measures. And he gave it to the poor and to the fatherless children ....") $)^{8}$ and GospThom 77

6 The earliest description of the "Ebionites" as group is that of Irenaeus, who reports that they rejected the virgin birth (Haer 3.2.7). Origen (Celsus 5.61; cf also his Commentarium in Evangelium Matthaei 16.12) mentions two groups of Ebionites, but without saying what distinguished them from each other. This information was supplied by Eusebius (HE 3.27 [Lake, Loeb]). One group, Eusebius writes, contends that Christ is an "ordinary and common human ... born to Mary and her spouse in the natural way", while the other "does not deny that the Lord was born of a virgin and the Holy Ghost". However, Eusebius could have confounded the latter group with those responsible for the Gospel of the Hebrews. Epiphanius, who quotes fragments of the Gospel of the Ebionites, is probably the best source of information about the Ebionites. He states that the Ebionites maintained that Jesus was no ordinary person, but could rather be compared to an archangel (Panarion 30.14.5) (see the discussion in Klijn 1992:14-16).

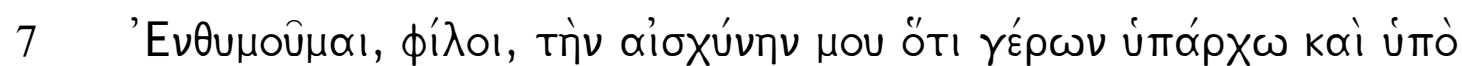

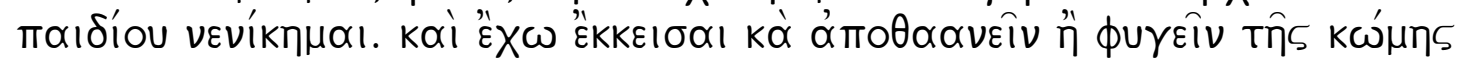

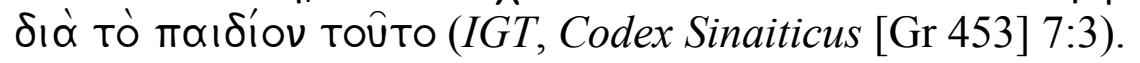

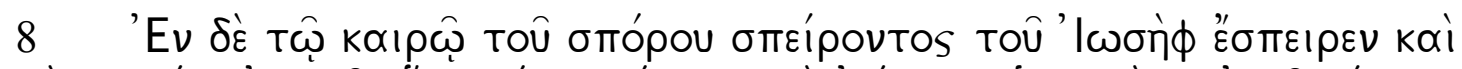

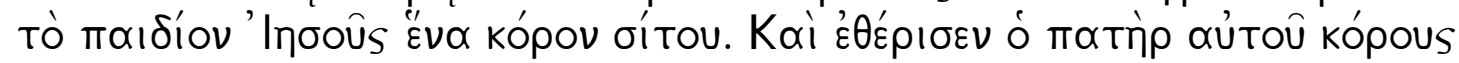


("split a piece of wood, I am there") with $I G T$, Codex Sinaiticus ( $\mathrm{Gr}$ 453) 16 ("Again, when a certain young man was splitting wood in equal parts, he cleft the sole of his foot and died as a result of loss of blood. When a commotion arose, Jesus ran [there] and after he had made his way through the crowd, he grabbed hold of the wounded foot and it was immediately healed. And he said to the young man: 'Go, chop your wood"') ${ }^{9}$.

My evaluation of the possibility that the $I G T$ might breathe a "Gnostic" spirit, based on its familiarity to the author(s) of the Acts of Thomas and the above allusions in the Gospel of Thomas, produced three results. First, I was able to indicate that the name "Thomas" does not occur in the most authentic manuscript of the $I G T$; second, that this manuscript does not contain a "Gnostic" view on redemption; and third, that the IGT did not originate in a Syrian or Egyptian context, which is probable in the case of the Gospel of Thomas $^{10}$. It is possible that the reference to the IGT in the Acts of Thomas $79^{11}$ indicates a "Gnostic" orientation with regard to the

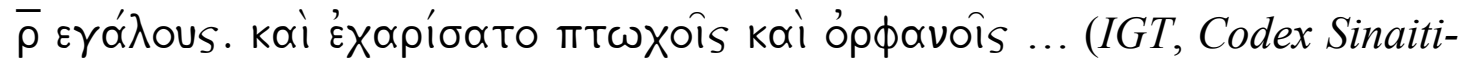
cus [Gr 453] 11:1-2a).

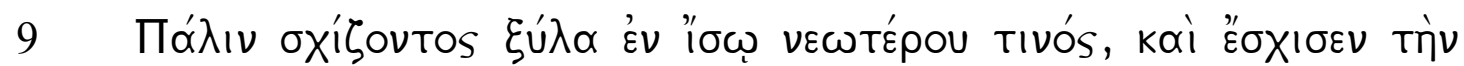

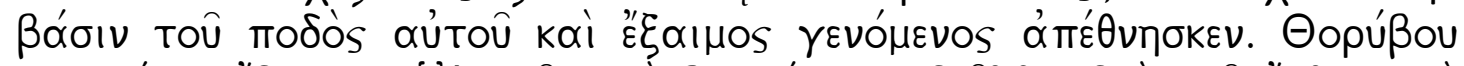

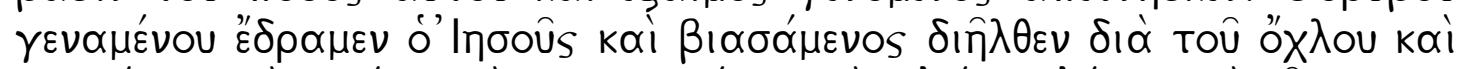

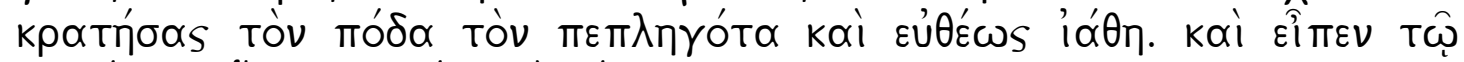

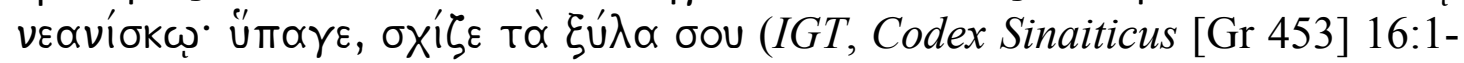
2).

10 Since the discovery of the Nag Hammadi library in Upper Egypt in 1945 (see Robinson 1998:77-110), the Gospel of Thomas takes centre stage as far as "Gnostic" literature is concerned (see Patterson 1998:33-75). However, whether the Gospel of Thomas can indeed be characterised as "Gnostic" is a moot point (see Riley 1994:229). Quispel $(1981,1991)^{10}$ thinks that it contains "encratic" (i.e. "ascetic") tendencies, originating from "Jewish-Christian" and Hermetic sources. ${ }^{10}$ Baarda (1988:200) calls "the present collection of sayings known as the Gospel of Thomas [is] a Gnostic florilegium". Koester's (1992:21) view is that the tendencies in the Gospel of Thomas are of a "radicalencratic" nature with a Gnostic orientation. Uro (2003) regards both the Gospel of Thomas and the Dialogue of the Redeemer as "gnosticizing" (see Davies 2004:670-671).

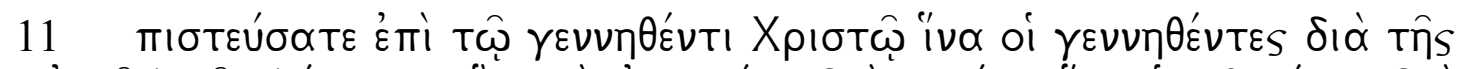

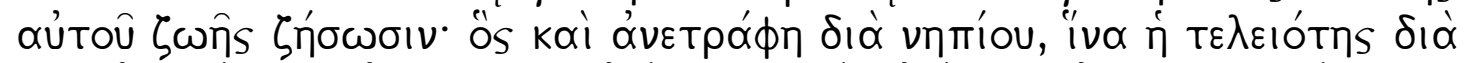
тоû å 
$I G T$. But it cannot be determined at all on which manuscript version of the IGT this statement in the Acts of Thomas is based.

My investigation did confirm that "Gnostic" tendencies were present in certain of the Greek manuscripts as well as in early translations of the $I G T$. However, I think I was able to show that the authentic Greek manuscript in Codex Sinaiticus (Gr 453) kept out these tendencies and that this authentic version of the IGT rather reflects Ebionite tendencies instead. In my opinion, the parallels in content between the $I G T$ and the other Thomas-related texts are too insignificant to connect material in IGT, Codex Sinaiticus (Gr 453) with the "Gnostic"orientation in the Thomas literature.

I think I was furthermore able to demonstrate that the $I G T$ should not be regarded as part of the Thomas literature. The absence of Thomas's name in the earlier versions of the IGT (Syrian and Georgian manuscripts, the manuscript Tblisi, Codex A 95; Old Latin manuscripts via Irenaeus) indicate that a Thomas authorship of $I G T$, Codex Sinaiticus (Gr 453) was both late and unknown in the Syrian milieu.

If, then, a "Gnostic" context for the IGT cannot be inferred on the basis of a suspected relation between the IGT and the Gospel of Thomas, the question is whether Irenaeus' reference to the IGT (in Haereses 1.20.1), like those in the Acts of Thomas, does not indicate a "Gnostic" orientation for the IGT. Irenaeus states explicitly that

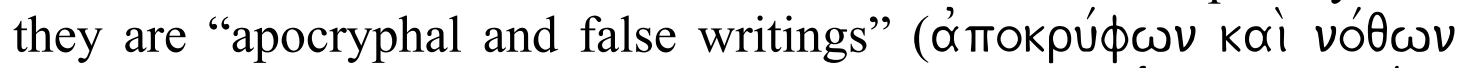

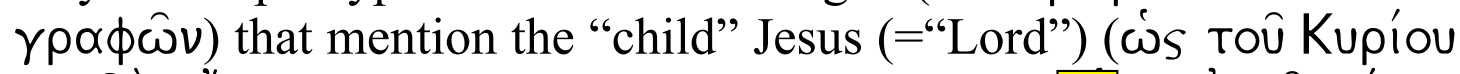

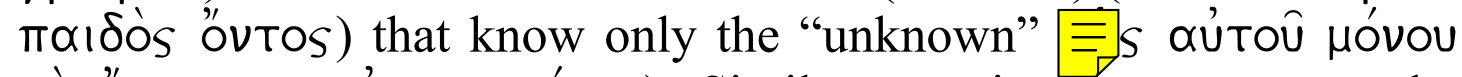

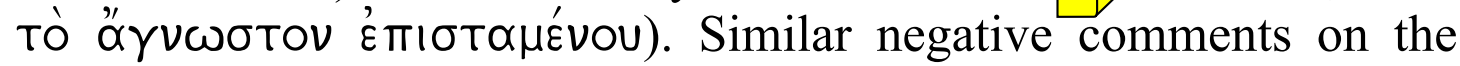
IGT are found in John Chrysostoms' Homilies on John (Homilae in Joannem $(17)^{12}$. On the other hand, the references in the Gospel of

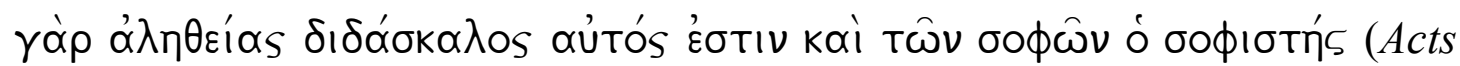
of Thomas 79 [CANT 245], text in Lipsius \& Bonnet [1891-1903] 1959:99291): "Believe in Christ, who was born so that those who are born may live through his life, who also grew up as a child so that the full maturity may come from his maturity. He taught his own disciples (Latin text: his own teacher [magistrum suum]), because he is the teacher of truth and the wisest of the wise".

12 "Therefore, in short, it is clear to us that the miracles that some people ascribe to the childhood years of Christ are false and merely concoctions of

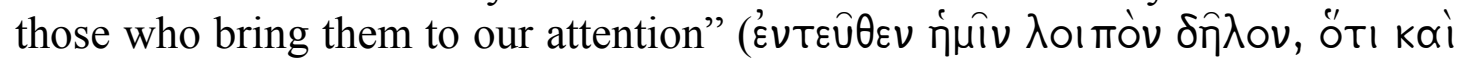


Bartholomew $(2: 11)^{13}$ and those in the History of Joseph the Carpenter (17) ${ }^{14}$ do not contain any comments that can be related to "Gnostic" tendencies at all.

\section{A GNOSTIC ORIENTATION?}

It is problematic to interpret Irenaeus' negative remarks about the $I G T$ as if they implied undoubtedly "Gnosticism" as such. Any attempt to give a "definition" of what "Gnosticism" could have been in the first two centuries CE is easier said than done. The literature of the Church Fathers does not help to formulate an unambiguous description of "Gnosticism" - even when fourth-century Manichaeism $^{15}$ is seen as the "culmination" and "conclusion" of what was known as "gnosis" (Markschies 2003:101-108).

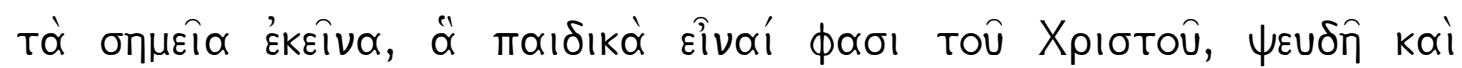

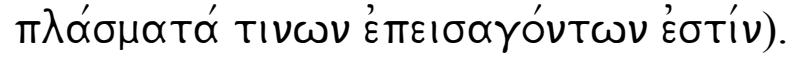

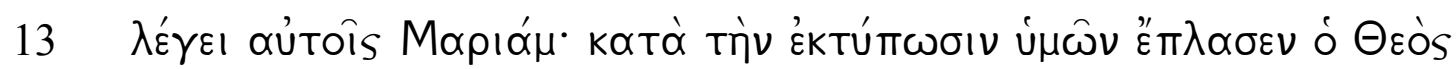

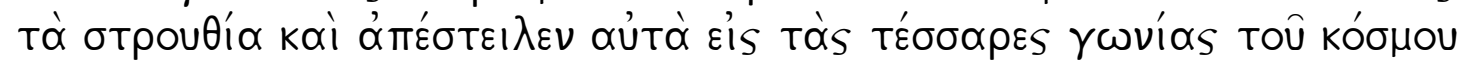
(Gospel of Bartholomew 2:11 [CANT 63], text in Vassiliev, A 1893, Anecdota graeco-byzantina, 1, 1, 10-22): "Mary told them [the apostles]: 'God created, corresponding to your parable, the sparrows and sent them to the four corners of the earth"”.

14 "O Lord, do not for this reason wish me harm, because I was ignorant of the mystery of your birth. I also remember, my Lord, the day when the boy died of snakebite. And his family wanted to deliver you unto Herod, because they said you had killed him, but you resurrected him from the dead and gave him back to them. Then I went to you and took your hand and said, 'My son, look after yourself.' But you answered me, 'Are you not my father in the flesh? I will instruct you about who I am" (History of Joseph the Carpenter 17 [CANT 60], translation based on the English translation by $\mathrm{J} \mathrm{K}$ Elliott (1993:114-117) from Coptic.

15 Roukema (1998:154) summarises the "myth designed by Manes [born in 216 CE in Ctesifon on the Tigris in Babylonia]" as follows: "All sorts of elements from this can be traced back to the Persian religion, but the influence of the apostle Paul and of Marcion and the Christian gnosticism can also be found back in Manes' system. Manes' adherents must be distinguished into 'the chosen' or 'the perfect', who lived unmarried and ascetic, and 'the hearers', who went less far in their compliance with the precepts and were allowed to marry ... According to Manes, reincarnation awaits the souls of the hearers after their earthly life as a rule, whereas the souls of the perfect share in the redemption when they die. The ultimate purpose of the world is, according to 
If a kind of characteristic "typology" of the many-coloured "Gnosticism" during the period of the earliest manuscript history of the IGT can be given, it is that the concept of "gnosis" relates to insight coming from God in (a) the "nature" of God, (b) the origins of a variety of "spiritual powers", (c) the origins of creation, (d) the purpose of existence on earth, and (e) the way in which "spiritual redemption" can be obtained (Roukema 1998:13). The assumption of this "gnosis" is that being human has in itself a latent/hidden divine/eternal/heavenly core of which the origin lies with "God Almighty", that the purpose of life on earth is to become aware of this origin and that some people are in fact reconciled with "God Almighty" through "true gnosis". This redemption takes place as a process in nature, and not only when the earthly life is laid down upon death ${ }^{16}$.

\section{AN EBIONITE CONTEXT?}

The connection I detected between the content of the $I G T$ and tendencies in Ebionite gospels did not turn the $I G T$ into one of the so-called "Ebionite gospels" Trans-Jordanian regions, and they are closely related to Jesus' biological family. In particular, my thesis aims to demonstrate that this positive relation is a particularly important element in the $I G T$ (contra Chartrand-Burke 2001) ${ }^{18}$. According to the opening verse in Codex Sinaiticus [Gr 453] 1:1, Jesus - being an child (Tó maı́íov

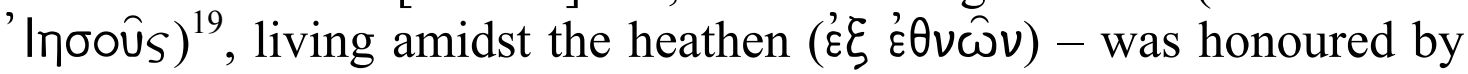

Manes, that light and dark are again completely separated and that the dark will never again be able to attack the light" (my translation from original Dutch).

16 See examples in the Gospel of Mary and Gospel of Philip, as discussed by Karen King (2003:37-81).

17 The Gospel of the Nazareans, the Gospel of the Ebionites, and the Gospel of the Hebrews (see Schonfield 1936; Munck 1959/60:103-116; Daniélou 1964; Schoeps 1969; Koch 1990:488-491).

18 A range of Jesus groups, especially in the first centuries, had close ties to the same traditions, and some second-century authors, including Justin and Origen, constantly attempted to establish such a relationship. Acknowledgement is hereby given to Dr Joseph Verheyden [2004], Catholic University of Leuven, who put his unpublished manuscript "Epiphanius on the Ebionites" at my disposal for the purpose of my research.

19 The motif that the presence of the "child Jesus" implies redemption occurs in two strategic places in the IGT, Codex Sinaiticus (Gr 453), namely in 


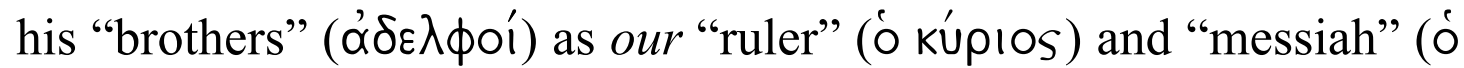
Xpıotós). This tribute signals the central matter in the message of the IGT. The addressees are, like the addresser, "Israelites" surrounded by heathen nations.

In his work "Literary dynamics: How the order of a text creates its meaning", M Perry (1979/80:35-64, 311-364) showed how the opening verses of an ancient narrative often determine the further development of the plot. The key to the context of the $I G T$ therefore lies in the translation of the opening words: "I, Thomas the Israelite, deemed it necessary proclaim to all the brothers living amidst the

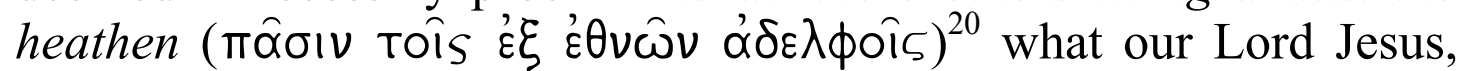
the Christ, did when he was born in Bethlehem, in the village of Nazareth. The beginning thereof is as follows" (my emphasis) ${ }^{21}$. The function of the proposition ${ }^{\prime} \xi \xi$ in the phrase ${ }^{\prime} \xi \xi$ $\xi \theta \nu \omega \hat{\omega} \nu$ can be understood as locally indicative in the place of $\varepsilon \mathrm{V}$ (see Blass / Debrunner 1970:272, §437). The reference to Bethlehem and Nazareth as the combined "birthplace" of the child Jesus is comparable to the Lucan diction in Peter's speech in Acts 10:39. Here Luke reports about the miraculous acts of "Jesus of Nazareth" (Acts 10:38) "in the land of the Jews and in Jerusalem" ( $\pi \alpha \dot{v} \tau \omega \nu$

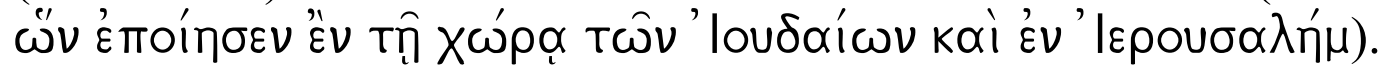

In the "opening verse" of the IGT both the author and his readers are called "Israelites" and "brothers" ( $\alpha \delta \varepsilon \lambda \phi o$ í) of one

$6: 4$ and 7:4. Both motifs - the redeeming presence of Jesus and the identity between Jesus and God - are related to the phenomenon that Jesus is mainly

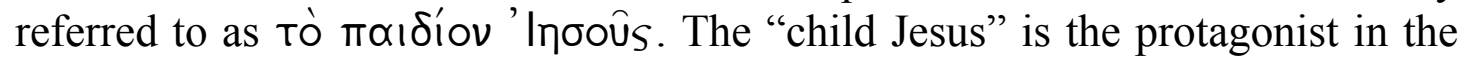
$I G T$ and the narrator combines the "identity" between Jesus and God with Jesus' redeeming acts as "child".

20 Ronald Hock (1995:105) translated these words as "I, Thomas the Israelite, am reporting to you , all my non-Jewish brothers and sisters." In other

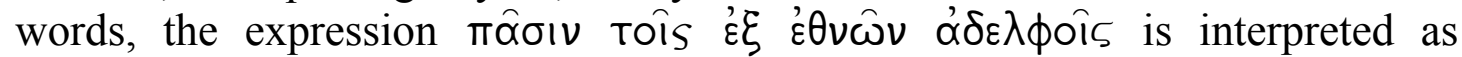
meaning that "Thomas, the Israelite" is writing to people who are not "Israelites" ("all my non-Jewish brothers and sisters"). Over against Hock, my translation above localises the author as an "Israelite" among those whom he addresses as "brothers".

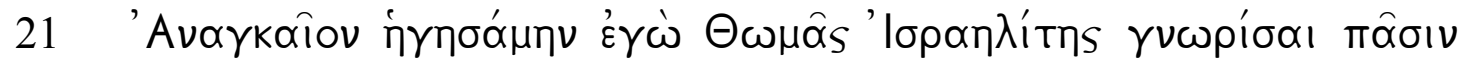

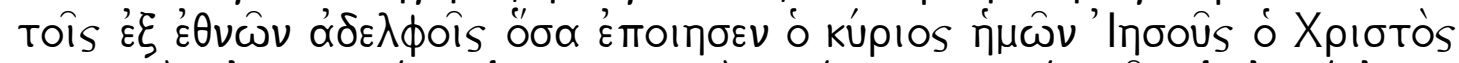

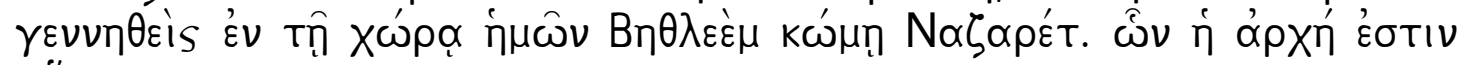
वütᄁ. 
another. They find themselves in a context between non-Israelites. The location can be anywhere in the second-century Diaspora. The regions of the Diaspora that would qualify as a possible social locality of the IGT that have agreements with the so-called Ebionite gospels should explain the distinct points of contact of the IGT with Luke's Western manuscript tradition. Given the indications of an early origin of the $I G T^{22}$, it is reasonable to assume a locus of composition in the middle of Luke's community or in a place where Luke's gospel was held in high esteem ${ }^{23}$. It extends from Rome (where Irenaeus places the Ebionites - see Klijn 1992:14-16) to Egypt (where Origen places them) and to Palestine (where Eusebius places them) (see Klijn 1992:28).

\section{A GOD-CHILD MYTH}

The Toronto doctoral dissertation of the Canadian Chartrand-Burke (2001) on the text, origin and transmission of the $I G T$ served as my basis for assessing the eleventh-century anonymous manuscript of Cyprus, namely the Codex Sinaiticus (Gr 453), which forms part of Von Tischendorf's compilation, as the most authentic. It is this Greek text that I translated into Afrikaans in my dissertation - which in itself was no small task! Tony Chartrand-Burke provided me electronically with her unpublished 2001 dissertation $^{24}$ with a view

22 These indications are the absence of apostolic authority, the lack of parallels with other New-Testament writings and the terminus ante quem on the basis of Irenaeus' knowledge of the IGT.

23 Walter Schmithals (1980:9) summarises the research of the matter as follows: "The typical theological views and concepts of the author do not come from the Pauline school ... The author of the two books [Luke-Acts] therefore remains unknown to us, but we will call him Luke. He was undoubtedly a converted heathen, and he writes for non-Jewish Christians ... It is not certain when the twin work was written. One must place it within the period 90-110, but it might be prudent not to move too far from the year 100. The place where the two books were written is also unknown; most probably Luke's community lived in the northwest of Asia Minor" (my translation from the original German.

24 Tony Chartrand-Burke is at present Professor at the Atkinson School of Arts and Letters, York University, Toronto, Canada. Because of the electronic format, references to page numbers in this work cannot be given. Where footnotes in her work are referred to, the title of the chapter in her unpublished work are added for closer identification. 
to a translation and own research. She meticulously compared the four extended Greek manuscripts.

Chartrand-Burke's analysis of the IGT's text, origin and history of transmission as well as the work of Ronald Hock redirected my thinking on the IGT. Textual critically seen, these works are not only a definite improvement on numerous earlier reproductions of the Greek text; they also constitute the current leading edge of the research done on the $I G T$. Unlike Lapham (2003:131), both Hock and Chartrand-Burke deny points of contact between the IGT and the Nag Hammadi Gospel of Thomas and Gnosticism and prefer comparisons with ancient biographic literature.

Ronald Hock (1995:96) explains the heroic exploits of the child Jesus in the $I G T$ as if he were an adult by saying that the readers of ancient biographies would not expect personality development in a character. In this respect it is worth mentioning that in the bookshop of the American University in Cairo I came across the work of Henri Daniel-Rops in which he speaks of "children copying grown-ups" (Daniel-Rops [1959] 1988:112).

In the ancient Mediterranean world, a specific personality was assumed as from birth. Chartrand-Burke's interpretation is that the author of the IGT sees his "young Jesus" no different than the Jesus and the apostles of the New Testament. In her view, Jesus in the IGT is neither a "Gnostic redeemer" nor a "god-child". In the $I G T$, Jesus is adult-like and wise, because according to the social expectations of his time, his heroic deeds confirm his humanity.

My interpretation is that the phenomenon that the author of the Greek version of the IGT in Codex Sinaiticus (Gr 453) describes the miracles of Jesus in a positive and a negative light as if he were an adult should be understood in light of the fact that the IGT is presented not so much in the genre of a Gnostic redeemer myth, but rather as a god-child myth. The scrutiny of the manuscript and translation history of the IGT confirmed this decision. It also motivated me to attend in the exegesis of the $I G T$ to the theory of the myth and to hermeneutics.

The tales in the Codex Sinaiticus (Gr 453) ${ }^{25}$ are probably derived from a large variety of sources which were orally transmitted

25 Codex Sinaiticus (Gr 453) was known in Greek to authors since the second century AD, among others: Irenaeus (Haer 1.20.1 - Greek text and 
tales about either the adult or the young Jesus and often imitated childhood tales about other honoured persons. Some tales could have been the author's own inventions.

In my dissertation I argued that the IGT is a "myth" in the form of a certain "gospel type", namely the "biographic-discursive" gospel. This means that the text represents a combination of a speech and a narrative. Such a genre is not foreign to early Christian "gospel-type" material ${ }^{26}$. What makes the IGT different from other biographic-discursive early Christian texts, for example the Letter of the Apostles (Epistula Apostolorum and the Acts of John (Actae Johannae), is that it is cast in the form of a god-child myth.

Post-modern interpreters of myths are increasingly becoming aware of the overlap that exists between the interpretation of myths and the interpretation of metaphors. Such hermeneutics demand a sensitivity for the qualitative difference between pre-modern and modern "spiritualities". According to scholars such as Freud ([1953] $1965)^{27}$ and Jung ([1956] 1967:17), as well as Bultmann (1965:128137) and Jonas (1969:315-329), spirituality in mythical thinking in

English translation, in Chartrand-Burke 2001, "Scholarship"), Epistula Apostolorum 4 (2nd century - Clavis Apocryphorum Novi Testamenti [CANT] [edited by M Geerard 1992] 22; 2d c [from the English translation of the Ethiopian version]), Acts of Thomas 79 (CANT 245 - text in Lipsius \& Bonnet [1891-1903] 1959:99-291), Gospel of Bartholomew 2:11 (4th century - CANT 63 [text in Vassiliev, A 1893, Anecdota graeco-byzantina, 1, 1, 10-22]), History of Joseph the Carpenter 17 (CANT 60 - translation based on J K Elliott's [1993:114-117] English translation from Coptic), Chrysostom (Homilae in Joannem 17 - in Patrologia Graeca [edited by J-P Migne] 59:410), Epiphanius (Panarion 51.20.2-3 - in Patrologia Graeca [edited by J-P Migne] 41:923D-925A).

26 As regards the "gospel-type" texts, John Dominic Crossan (1998:31-40) distinguishes four different "types" of gospels. He calls the four canonical gospels a biographic gospel. The Gospel of Thomas and $Q$ represent the type proverb gospel. ${ }^{26}$ The Secret Gospel of James is a discursive gospel and the Letter of the Apostles (Epistula Apostolorum) and the Acts of John (Actae Johannae) are examples of biographic-discursive texts.

27 According to Claude Lévi-Strauss, on the other hand, Freud assessed myth from his modernistic position and not in terms of a pre-modern mythological worldview (see Lévi-Strauss \& Doniger et al 1995). In his opinion, Freud merely produced a modern version of it while pretending to return to the original myth (Lévi-Strauss, in Segal 1999:154 note 10). 
the pre-modern era differs fundamentally from that in the modern (natural sciences) era. The former can be called "fantasy-thinking" (mythos) and the latter as "rationalistic thinking" (logos) (cf Segal 1999:81-84).

It should therefore be taken into account that the "logical thinking" of people in the modern era is thinking that has been adapted to empirical reality. Modern people arrange their thinking logically in the sequence in which things happen one after the other in empirical reality, like death following birth (see Jung 1967:11). Pre-modern mythical thinking can be described as spontaneous, associative and "unidirectional" (see Jung 1967:17).

In the case of the $I G T$, preconceptions arising from the modern paradigm led to the text not being evaluated on merit, but in terms of criteria that conform to rationalistic criteria. Bultmann's ([1958] 1964:15) dialectical distinction between mythology (= worldview) and myth (= an objectifying language act as an expression of such a worldview) eliminates such an fallacy and makes a hermeneutic approach possible. The hermeneutic therefore interprets myth tautegorically and not allegorically (see Cassirer 1955:62).

An allegoric interpretation of myth approaches the mythical text from the interpreter's epistemological assumptions about what can be "true" and what can be regarded as "meaningful". These assumptions arise from the interpreter's worldview and do not form part of the worldview in which the myth itself is embedded as a language act. A tautegoric interpretation sees meaning and assesses the truth thereof on the basis of other criteria. The worldview of the myth is indeed experienced as "different", but the meaning of the myth is not interpreted as so "strange" that it needs to be changed by means of allegorising (cf. Schultz 2000:162). Such an interpretation does not mean that the myth is transmitted "literally" and unchanged, but it is transmitted in such a way that "the same" message is communicated ${ }^{28}$. "Allegoric" means "to communicate

28 The term "tautegoric" is derived from the Greek words to tauto (Tò

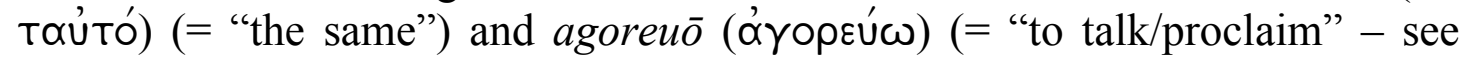
Liddell \& Scott ([1843] [1940] 1961:13-14) and "allegoric" from the words

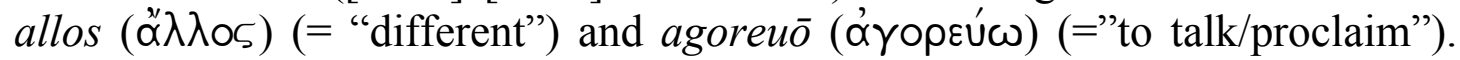
Etymologically, "tautegoric" means "to communicate the same". In Homer

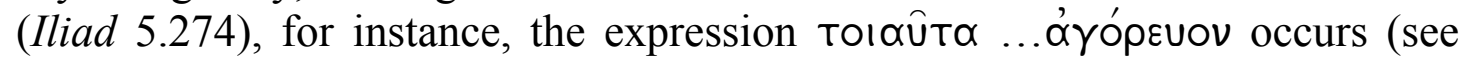
Liddell \& Scott 1961:13). Hermeneutically, tautegory refers to a determination 
differently" and indicates the interpretation of language as a symbol of communication within another worldview. The hermeneutic approach attempts to "interpret" the earlier communication in an ancient worldview in a non-allegoric and non-positivistic way so that it can communicate in an existentialistic manner in a later context.

This leads, inter alia, to myth not being interpreted as something non-mythical in an allegoric or empirical-positivistic way. Hans-Josef Klauck (2003:77) proposes that the message of the $I G T$ should be understood "symbolically". With this he probably means "allegorically". Chartrand-Burke, on the other hand, interprets the author's message as a "metaphor" that would allegorically relate to a kind of "personification" of Christian claims of superiority in the early church. According to her, the Christians in the early church could have seen themselves in the young Jesus, because as an early Christian (i.e. "young") community, they also went through a difficult "infancy". In this context, they - with regard to the teachings and practices of Formative Judaism, but also with regard to the non-Israelite systems of faith - often found themselves to be in conflict with Israelites and gentiles. The curses of the "child Jesus" would then allegorically indicate a veiled threat against anyone who would oppose this early Christian community. As a Jesus "cursing" others would be hard to accept from a present-day Western perspective, but cannot be denied after an empirical scrutiny of the text, the "unacceptability" is interpreted differently by understanding it positively as an allegory of the rejection of the church.

However, approaching myth from a post-modern perspective by explaining it in the same way in which non-positivistic hermeneutics interprets the concept of "metaphor" opens the door to innovative thinking. Regarding "myth" as both a narrative and a worldview (paradigm) helped me to approach the IGT hermeneutically as being representative of the hero myth and especially the god-child myth. Such a hermeneutic approach to myth prevents one from, on the one hand, ascribing the $I G T$ to "pious

of meaning of language as symbol of communication within the reference framework of the worldview in which it originates and for whom it is meant. (For his motivation of a "philosophic-scientific" use of etymology, see Cassirer [1945:115].) 
curiosity" (Klauck 2003:223) and on the other from subjecting it to historical allegorisation (Chartrand-Burke 2001).

The negative tales in the $I G T$ represent the pattern of a typically Mediterranean "honour/shame" conflict ("challengeriposte") between Jesus and the Israelite rabbis. When they confirm his divine superior wisdom (as in Luke's temple tale), Jesus acts as their friend, brother and son to the benefit of his family and neighbours (as extended family). When the rabbis do not acknowledge his wisdom, Jesus acts accordingly with punitive miracles $^{29}$.

Like Chartrand Burke, it is my view that the IGTs god-child Jesus must be regarded as "fully human" 30 . We also agree that the child Jesus is portrayed in the IGT in accordance with the sociohistorical expectations of that time (and I add the sociopsychological). This portrayal refers to Jesus' role as son, brother, friend and pupil in the IGT. Similar expectations of "adult children" are found other Hellenistic-Semitic and Graeco-Roman biographic literature as well. But we differ about the interpretation in that I understand the IGT as a god-child myth and locate its existential meaning within the context of the Ebionite early Christianity.

Jesus' "status" of god-child is manifested in various ways in the IGT. He possesses a maturity and wisdom that does not befit his youth. Even at the age of five Jesus responds with cryptic pronouncements and enigmatic doctrines to those around him ${ }^{31}$.

29 This is not to say that there are no other nuances in the IGT. It is possible, for instance, to interpret the curse on the son of Annas, - "your fruit (will be) without root and your sprout dried out like a branch that has been broken off by a strong wind" (IGT, Codex Sinaiticus [Gr 453] 3:2) - as vaticina ex eventu from a post $-70 \mathrm{CE}$ perspective. The implicit criticism of the Torah with regard to observation of the Sabbath (IGT, Codex Sinaiticus [Gr 453] 6:4) can also be understood as a polemic reference to the wisdom of the Israelite Second Temple elite.

30 Both Chartrand-Burke's and my opinions, however, are not deliberated from the perspective of a "pre-existent Christology" which, according to Klauck (2003:77), was introduced into the $I G T$ - a tendency that is not yet found in the infancy tales of Matthew and Luke.

31 The first indication of this occurs in Jesus' reply to his father's reprimand in IGT, Codex Sinaiticus (Gr 453) 5:3: 
The tale of "Jesus and the Teacher" forms the nucleus in the structure of the IGT. The first reference to it covers about one third of the document, and together with the additional teacher episodes it forms a threefold narrative that points towards the central theme in the message of this version of the IGT, namely that the child Jesus, and not the adult teachers, is the one who is teaching.

His divine wisdom is manifested especially in his meetings with rabbis and older persons (IGT, Codex Sinaiticus [Gr 453] 6:8$10 ; 8: 1 ; 13: 2 ; 14: 2-4 ; 17: 2-4)$. These "manifestations" elicit among the bystanders the sense that Jesus is somehow different: "either a god or an angel" (IGT, Codex Sinaiticus [Gr 453] 7:4).

As regards the "divinity" of the child Jesus, the portrayal of Jesus in the IGT shows a correspondence with the characteristics of an ideal in antiquity as can be seen in the portrayal of, inter alia, the young Moses ${ }^{32}$, Apollonius ${ }^{33}$, Heracles $^{34}$ and Plato ${ }^{35}$ - all of them

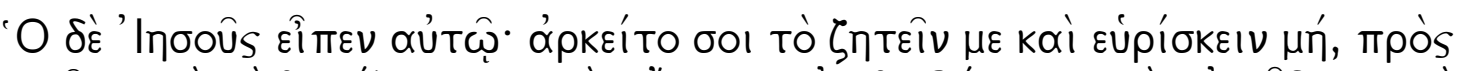

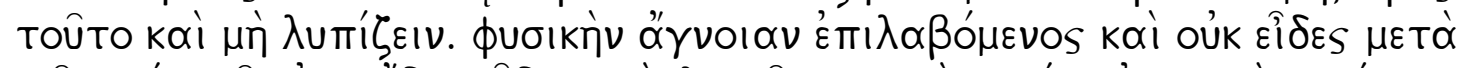

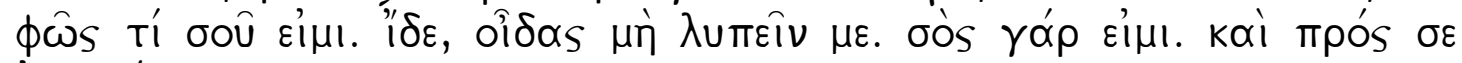

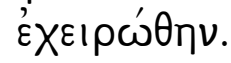

"And Jesus said to him: 'It is enough for you to look for me and not to find me, but you should not be sad about his. With an obvious ignorance, you do not even with light - know that I come forth from you. Look, you have no idea how to make me sad. Because I am yours, and I am surrendered to you."”

Shortly after, the "evelation discourse" of chapter 6 follows which made everyone who listened fall silent:

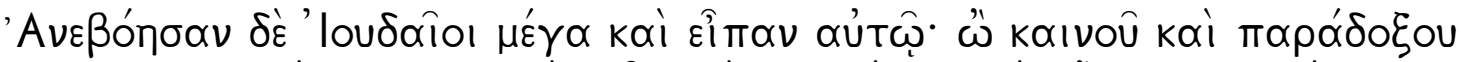

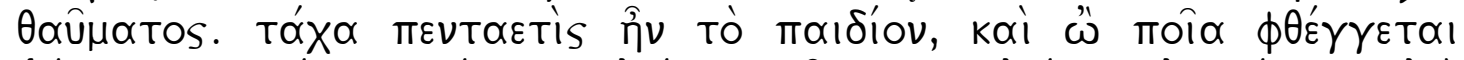

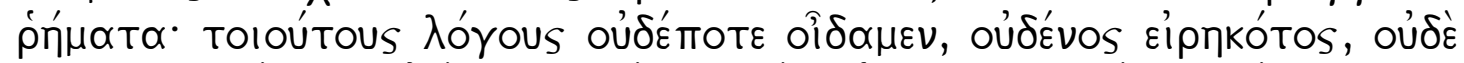

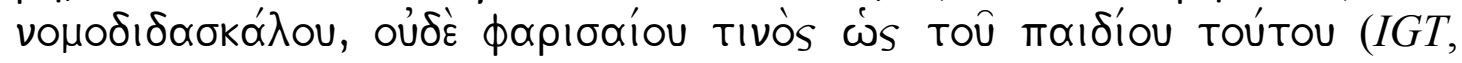
Codex Sinaiticus [Gr 453] 6:5).

"And the Judeans called out loud and said to him: 'Oh, what a new and incredible miracle! The little child is probably [only] five years old, and oh! what words he speaks! Such words we have never known; no one has ever said [this] except this child - neither a teacher of the law, nor a Pharisee!"”

32 In the Israelite context, the tales of Philo (De Vita Mosis 1.5-1.24) and Josephus (Antiquitates Judaicae 2.9.2-3, 6, 7; 2.10.1-2) about Moses are the best known. More tales can be found about Moses (Liber Antiquitatum Biblicarum [LAB] 9:10), Isac, Samson (Antiquitates Judaicae 5.8.1-4; LAB 42.1-10), Noah (1 Hen 106:11-19), Abraham (Job 11:14-24), Malachi (LifeProphets 16:1) and Elijah (LifeProphets 21:2). In the story of Elijah, the 
angels, who upon his birth appeared the prophet's father, wrapped him in "swaddling clothes of fire and gave him a flame of fire to eat" (LifeProphets 21:2 [Hare]). Josephus (Antiquitates Judaicae 5.10.4) also related that Solomon ascended the throne at the age of twelve, and the twelve-years-old Daniel possesses wisdom and spiritual maturity (see De Jonge 1978:323). The motif of adult wisdom in youth is so common in "Jewish" biographies that Josephus (Vita 9) even ascribed it to himself.

33 Of all the divines, Apollonius is the one compared to Jesus most often (see Kosenniemi 1994:18-168; 1998:456-468). As in the case of Jesus, the birth of Apollonius is prophesied; he is of both divine (Zeus) and human descent (his earthly parents); miracles occurred when he was born; from his youth, he was an authoritative teacher and healer; he was captured, charged and executed (as a magician); he arose from the grave. Hellenistic-Semitic authors such as Philo (De Vita Mosis 8.11.14), Josephus (Antiquitates Judaicae 2.280-288, 339; 3.3538, 179-180) and Artapanus (fragment 3) used the Apollonius model to interpret Moses for their audience. The young Jesus shares in the abilities ascribed to all these figures, and his miracles are passed on in the same literary forms.

34 The Hellenistic hero connected with Jesus most often is Heracles (see Ackermann 1907:323-428; cf Talbert 1977:26-43; Riley 1997:15, 52; for criticism of establishing such a connection, see Aune 1990:11-13). The tales of the life of Heracles indeed contain many significant similarities. Heracles was the son of Zeus, he suffered in order to carry out his famous twelve tasks, descended to the underworld, was put to death at the stake (ignited by a flash of lightning) and was declared, on the strength of an "empty grave" (no ashes or bodily remains were found) to be the son of Zeus, so that he could assume a place in the sphere of the gods (Diodorus Siculus, Bibliotheca Historica 38.35). Heracles also performed miracles in his childhood years: when Hera sends snakes into his crib, the infant in arms throttles them with his already awesome strength (Appollodorus 2.4.8), and as a boy he killed his teacher, Linos, over an unfair punishment (Appollodorus 2.4.9).

35 Plato was the only philosopher who was accorded divine veneration by Diogenes Laertius (see Riginos 1976:10 for the primary text reference). Diogenes (3.2) reports an anecdote in which divine paternity and virgin birth through the doing of Apollo (3.2) are ascribed to Plato, and like other highly esteemed philosophers and poets Plato begins to distinguish himself as a young adult. Theseus, for instance, anticipated his destiny as a future adult by using his already enormous strength as a child to move the stone under which the sword and the sandals (which his father had left him) were hidden (Plutarch, Theseus 3). The legends of Cyrus recorded by Herodotus (Historiai 114-15) depict this Persian king as a typical hero. After having been saved from exposure, the ten-year-old Cyrus is chosen as king during a game with other 
figures possessing superhuman wisdom. This ability and wisdom brings Jesus, like these figures, into the vicinity of the divine. Like these heroic figures, Jesus is a god-child. All the other tales in the $I G T$ reflect this theme and serve to demonstrate Jesus' power and authority as a god-child. From the moment he enters the classroom, this boy is already full of knowledge. He has never been taught, yet he can teach. Jesus' wisdom is of divine origin.

What is important to observe, however, is that this depiction of Jesus - although consistently analogous to the idealised representations of children in ancient biographies - was not idealised in this way because his parents wanted him to be like this. In this respect, the $I G T$ differs from the cultural convention concerning the societal expectations of parents from their children. The Jesus of the $I G T$ is himself the adult god-child, regardless what his family or friends or teachers expect him to be.

What we have in the IGT is not a human child idealised to godliness, but a god-child portrayed as human ${ }^{36}$. The point is not that the god-child Jesus was not really human and is therefore represented as human here ${ }^{37}$.

From the perspective of a social-scientific explanation, we can say that the narrator in this "biographic-discursive" infancy gospel depicts the young Jesus as mature and wise, not because he was really either human or not, but because his mature wisdom (while he is a child) makes him, the god-child, human. When Jesus is given this recognition, namely that this Jesus is a god-child - as the tales about the rabbis of Israel testify - the divine child acts humanely towards family and friends, like a son, brother and friend.

\section{Consulted literature}

Ackermann, E 1907. De Senecae Hercule Oetaeo. Philologus Supplementband $10,323-428$.

children. Fully aware of his royal role, the boy taunts a nobleman and then defends his conduct with an eloquence that does not match his youth.

36 However, reading docetic or adoptionist motifs into the text is to fail to distinguish the Greek version of the IGT in Codex Sinaiticus (Gr 453) from the other Greek versions of this infancy gospel.

37 This representation of Jesus is the consequence of "gnosticising", and all signs thereof in the sources were eliminated by the narrator in the Greek version of the IGT in Codex Sinaiticus (Gr 453). 
Aune, D E 1990. Heracles and Christ: Heracles imagery in the Christology or early Christianity, in Balch, D L, Ferguson, E \& Meeks, W A (eds), Greeks, Romans, and Christians: Essays in honor of Abraham J Malherbe, 2-19. Minneapolis, MN: Fortress Press.

Baarda, T 1988. "If you do not sabbatize the Sabbath ...": The Sabbath as God or world in Gnostic understanding (Ev.Thom., Log. 27), in Van den Broek, R, Baarda, T \& Mansfield, J (eds), Knowledge of God in the Graeco-Roman world, 178-201. Leiden: Brill.

Blass, F / Debrunner, A [1896] 1970. Grammatik des neutestamentlichen Griechisch, bearbeitet von A Debrunner. Göttingen: Vandenhoeck \& Ruprecht.

Bultmann, R [1958] 1964. Jesus Christus und die Mythologie. Hamburg: Furce. (Stundenbuch 47.)

-, 1965. Zum Problem der Entmythologisiering, in Glauben und Verstehen Gesammelte Aufsätze, IV, 128-137. Tübingen: Mohr.

Cassirer, E [1944] 1945. An essay on man: An introduction to a philosophy of human culture. New Haven, CT: Yale University Press.

Chartrand-Burke, T 2001. The Infancy Gospel of Thomas: The text, its origins, and its transmission. PhD dissertation, University of Toronto.

Crossan, J D 1998. The birth of Christianity: Discovering what happened in the years immediately after the execution of Jesus. San Francisco, CA: Harper SanFrancisco.

Daniélou, J 1964. The theology of Jewish Christianity. London: Darton, Longman and Todd.

Daniel-Rops, H [1959] 1988. Palestine at the time of Christ, tr by P O'Brian. London: Phoenix Press.

Davies, S 2004. Review article: Ristro Uro, Thomas: Seeking the historical context of the Gospel of Thomas. Catholic Biblical Quarterly 66, 670-671.

De Jonge, J 1978. Sonship, wisdom, infancy: Luke 2:41-51a. New Testament Studies 24, 317-354.

Delatte, A 1927. Évangile de l'enfance de Jacques: Manuscript No. 355 de la Bibliothèque Nationale, in Ancecdota Atheniensia, Vol 1: Textes grecs inédits relatifs à l'histoire des religions, 264-271. Paris: Edouard Champion.

De Santos Otero, A (ed) 1967. Das Kirchenslavische Evangelium des Tomas. Berlin: De Gruyter (PTS 6).

Eco, U 1984. The role of the reader: Explorations in the semiotics of texts. Bloomington: AiS (IUP).

Elliott, J K 1993. The apocryphal New Testament. Oxford: Clarendon Press.

Evans, G A, Webb, R L \& Wiebe, R A (eds) 1993. Nag Hammadi texts and the Bible: A synopsis and index. Leiden: E J Brill. 
Fabricius, J (Hrsg) 1703. Codex Apocryphus Novi Testamenti, Band 1, 159167. Hamburg: Schiller.

Freud, S [1953] 1965. The interpretation of dreams, tr by J Strachey. New York: Avon Books.

Geerard, M (ed) 1992. Clavis Apocryphorum Novi Testamenti. Turnhout: Brepolis.

Heidegger, M [1927] 1962. Being and time, tr by J Macquarrie \& E Robinson. Oxford: Oxford University Press.

Hervieux, J 1960. The New Testament apocrypha, tr by D W Hibberd. New York: Hawthorn Books.

Hock, R F 1995. The Infancy Gospel of Thomas, in Hock, R F, The Infancy Gospels of James and Thomas: With introduction, notes, and original text featuring the new Scholars Version translation, 84-158. Santa Rosa, CA: Polebridge Press (The Scholars Bible).

Inwood, M 2000. Heidegger: A very short introduction. Oxford: Oxford University Press.

Jonas, H 1969. Myth and mysticism: A study of objectification and interiorization in religious thought. Journal of Religion 49, 315-329.

Jones, S 1990. s v Ebionites, in Ferguson, E (ed), Encyclopedia of early Christianity, 297-288. New York: Garland Publishing.

Jung, C G [1956] 1967. Symbols of transformation: Collected works, vol 5. $2^{\text {nd }}$ edition. Princeton, NJ: Princeton University Press.

King, K 2003. The Gospel of Mary of Magdala: Jesus and the first woman apostle. Santa Rosa, CA: Polebridge Press.

Klauck, H-J [2002] 2003. Apocryphal Gospels: An introduction, tr by B McNeil. London: T \& T Clark.

Klijn, A F J 1992. Jewish-Christian gospel tradition. Supplements to Vigiliae Christianae 17. Leiden: E J Brill.

Koch, G A 1990. s v Jewish Christianity, in Ferguson, E (ed), Encyclopedia of early Christianity, 488-491. New York: Garland Publishing.

Koehler, L \& Baumgartner, W 1994-2000. The Hebrew and Aramaic Lexicon of the Old Testament, subsequently revised W Baumgartner and J K Stamm. Translated and edited under supervision of M E J Richardson. CD-ROM Edition. Leiden: Koninklijke Brill NV.

Koester, H 1992. The story of the Johannine tradition. Sewanee Theological Review 36, 17-32.

Koskenniemi, E 1994. Apollonios von Tyana in der neutestamentlichen Exegese: Forschungs-bericht und Weiterführung der Diskussion. Tübingen: Mohr-Siebeck (WUNT 2.61). 


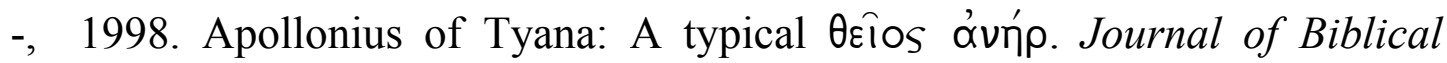
Literature 117, 455-467.

Lapham, F 2003. An introduction to the New Testament apocrypha. London: T\&T Clark International (A Continuum Imprint).

Lévi-Strauss, C \& Doniger, W et al 1995. Myth and meaning: Cracking the code of culture. New York: Schocken Books.

Liddell, H G \& Scott, R [1843] [1940] 1961. A Greek-English lexicon. A new edition, revised and augmented throughout by $\mathrm{H}$ S Jones with the assistance of R McKenzie. New (ninth) edition. Reprinted. Oxford: Clarendon Press.

Lipsius, R A \& Bonnet, M (eds) [1891-1903] 1959. Acta apostolorum apocrypha. Reprinted. Darmstadt: Wissenschaftliche Buchgesellschaft.

Markschies, C [2001] 2003. Gnosis: An introduction, tr by J Bowden. London: $\mathrm{T} \& \mathrm{~T}$ Clark.

Migne, J-P [1856] 1989. Dictionnaire des Apocryphes, 2 vols. 1856. Reprinted. Turnhout: Brepols.

Munck J 1959/60. Jewish Christianity in post-apostolic times. New Testament Studies 6, 103-116.

Noret, J 1972. Pour une édition de l'Évangile de l'enfance selon Thomas. Analecta Bollandiana 90, 412.

Patterson, S J 1998. Understanding the Gospel of Thomas today, in Patterson, S J, Robinson, J M \& Bethge, H-G 1998. The Fifth Gospel: The Gospel of Thomas comes of age, 33-75. Harrisburg, PA: Trinity Press International.

Perry, M 1979-1980. Literary dynamics: How the order of a text creates its meaning. Poetics Today 1, 35-64, 311-364.

Quispel, G 1991. Review of Layton, B 1989, Nag Hammadi Codex II, 2-7 (Nag Hammadi Studies 20; 2 vols), Leiden: Brill. Verbum Caro 45, 78-87.

Riginos, A S 1976. Platonica: The anecdotes concerning the life and writings of Plato. Leiden: Brill (Columbia Studies in the Classical Tradition 3).

Riley, G J 1994. The Gospel of Thomas in recent scholarship. Currents in Research: Biblical Studies 2, 227-252.

Riley, G J 1997. One Jesus, many Christs: How Jesus inspired not one true Christianity but many. San Francisco, CA: Harper Collins.

Robinson, J M 1998. Nag Hammadi: The first fifty years, in Patterson, S J, Robinson, J M \& Bethge, H-G (eds.). The Fifth Gospel: The Gospel of Thomas comes of age, 77-110. Harrisburg, PA: Trinity Press International.

Roukema, R 1998. Gnosis \& geloof in het vroegste Christendom: Een inleiding tot de gnostiek. Meinema: Zoetermeer.

Schonfield, H J 1936. The history of Jewish Christianity: From the first to the twentieth century. London: Duckworth. 
Schmithals, W 1980. Das Evangelium nach Lukas. Zürich: Theologischer Verlag (Zürcher Bibelkommentare).

Schneider, G 1995. Evangelica Infantiae Apocrypha/Apokryphe Kindheitsevangelien. Freiburg i.Br.: Herder (FC 18).

Schoeps, H-J 1969. Jewish Christianity. Philadelphia, PA: Fortress.

Schultz, W 2000. Cassirer and Langer on myth: An introduction. New York: Garland Publishing.

Segal, R A 1999. Theorizing about myth. Amherst, MA: University of Massachusetts Press.

Talbert, C H 1977. What is a gospel? The genre of the canonical gospels. Philadelphia, PA: Fortress Press.

Uro, R 2004. Seeking the historical context of the Gospel of Thomas. London: Clark.

Van Aarde, A G 2004. The earliest Jesus group in Jerusalem. Verbum et Ecclesia 5(2), 711-738.

-, 2005. Die Kindheidsevangelie van Tomas as ' $n$ heroïese mite van die godkind Jesus in die konteks van die Ebionitiese Christendom. DLitt-proefskrif, Universiteit van Pretoria.

Vassiliev, A 1893. Anecdota graeco-byzantina, 1. Moscow: Universtitatis Caesareae.

Verheyden, J [2004]. Epiphanius on the Ebionites. Unpublished manuscript, provided by Verheyden to the author of this study [J Verheyden, A Thierylaan 32, B-3001 Leuven, Belgium].

Voicu, S J 1991. Notes sur l'histoire du texte de L'Histoire de l'Enfance de Jésus. Apocrypha 2, 119-132.

Voicu, S J 1997. Histoire de l'enfance de Jésus, in Bovon, F \& Geoltrain (eds), Écrits apocryphes chrétiens, I, 191-196, 197-204. Paris: Gallimard.

Von Tischendorf, C [1854] 1876. Evangelica Apocrypha. 2.Auflage. Leipzig: Avenarius and Mendelsohn.

Weissengruber, F 1978. Grammatische Untersuchungen zum Thomasevangelium A, in Fuchs, A \& Weissengruber, F (Hrsg), Konkordanz zum Thomasevangelium, Version A und B, 205-226. Freistadt: Plöchl. 